\title{
"I write short-short stories while I am writing a novel" Interview with Nuala NíChonchúir
}

\author{
Marisol Morales \\ Universidad de Alcalá de Henares, Spain
}

Copyright (c) 2014 by Marisol Morales-Ladrón. This text may be archived and redistributed both in electronic form and in hard copy, provided that the author and journal are properly cited and no fee is charged for access.

Nuala NíChonchúir is an award-winning and talented poetry and fiction writer with a wide-ranging literary production. She has explored all literary genres and has addressed a great variety of themes, most of them connected with gender issues, male and female troubled relationships, sex, the body, the visual arts, the family and the mother-son/daughter bond, among others. Born in Dublin, in 1970, she holds a BA in Irish from Trinity College Dublin and an MA in Translation Studies (Irish/English) from Dublin City University. She now lives in Co. Galway, where she writes full time and teaches creative writing courses.

Nuala NíChonchúir has published one novel, You (2010). Her second, The Closet of Savage Mementos, is due in spring 2014 and her third one, Miss Emily, has just been accepted for publication by Penguin USA and Penguin Canada. NíChonchúir has also authored four short story collections, The Wind Across the Grass (2004), To The World of Men, Welcome (2005), Nude (2009) and Mother America (2012), and has recently published a chapbook of flash fiction, entitled Of Dublin and Other Fictions (2013). Her poetic production includes the titles Molly's Daughter (2003), Tattoo: Tatú (2007), Portrait of the Artist With a Red Car (2009) and The Juno Charm (2011). She has also cowritten a play, Departures, with three other writers and she is now guest editor of the spring 2014 edition of The Stinging Fly. NíChonchúir has been awarded several prizes, among which we could mention the Cúirt New Writing Prize, the RTÉ radios Francis MacManus Award in 2002, for her short story "The Wind Across the Grass", and the 2013 Thresholds International Short Story Feature Writing Competition, for her essay "A Trio of Irish Short Stories". Her third short story collection, Nude, was shortlisted in 2010, followed by her fourth, Mother America, which was also long listed for the Edge Hill Short Story Prize in 2013.

I had the pleasure to meet Nuala NíChonchúir in Cáceres last May 2013 during the celebration of the XIII Conference of AEDEI, to which she had been invited as a guest writer, sponsored by the Embassy of Ireland in Madrid. She read from her work and additionally gave an insightful plenary lecture entitled "Choosing $Y O U$ - the second-person voice in two Irish novels". The following interview took place in the course of the conference and has been updated in the last months through personal meetings and correspondence on the matter of her subsequent publications and literary success.

Key Words. Nuala Níchonchúir, You, Second-Person Narrative, Male-Female Relationships, Body, Women Writers, Irish Tradition.

1. The research carried out for the writing of this article has been financed by the Spanish Ministry of Economy and Competitiveness, previously Ministry of Science and Innovation (MINECO, research project FFI201123941).

ISSN 1699-311X 
Nuala NíChonchúir, autora de poesía y ficción, es una voz emergente y reconocida ya en la literatura irlandesa, que cuenta con una amplia y variada producción. Ha explorado todos los géneros literarios y ha tratado temas tan distintos como cuestiones de género, relaciones difíciles ente hombres y mujeres, el sexo, el cuerpo, el arte, la familia o el vínculo madre-hijo/a, entre otros. Nacida en Dublín, en 1970, se graduó en Irlandés en Trinity College Dublin y posteriormente hizo un Máster en estudios de Traducción (irlandés/inglés) en Dublin City University. Ahora vive en el condado de Galway, donde se dedica a escribir e impartir cursos de escritura creativa.

Hasta la fecha, Nuala NíChonchúir ha publicado una novella, You (2010). Su segunda, The Closet of Savage Mementos, saldrá en primavera de 2014 y su tercera novela, titulada Miss Emily, acaba de ser aceptada por la editorial Penguin USA y Penguin Canada. NíChonchúir es también autora de cuatro colecciones de historias cortas, The Wind Across the Grass (2004), To The World of Men, Welcome (2005), Nude (2009) y Mother America (2012), y recientemente ha publicado un pequeño libro de "flash fiction", o narrativas muy, muy breves, titulado Of Dublin and Other Fictions (2013). Su producción poética incluye los títulos Molly's Daughter (2003), Tattoo: Tatú (2007), Portrait of the Artist With a Red Car (2009) y The Juno Charm (2011). Asimismo, ha escrito la obra de teatro Departures, en colaboración con otros tres escritores, y este año es editora invitada para la edición de primavera de la revista The Stinging Fly. La extensa obra de NíChonchúir ha sido reconocida con muchos premios literarios, entre los que podríamos mencionar el Cúirt New Writing Prize, el RTÉ radios Francis MacManus Award en 2002, por su historia "The Wind Across the Grass", y el Thresholds International Short Story Feature Writing Competition del 2013, por su ensayo "A Trio of Irish Short Stories". Su tercera colección de narrativa breve, Nude, fue nominada en 2010, seguida de la cuarta, Mother America, que también fue seleccionada para el Edge Hill Short Story Prize en el año 2013.

Tuve el placer de conocer a Nuala NíChonchúir en Cáceres el pasado mes de mayo de 2013, durante la celebración del XIII Congreso de AEDEI, al que había sido invitada gracias al patrocinio de la Embajada de Irlanda en Madrid. Nula leyó diversos fragmentos de su obra e impartió una conferencia titulada "Choosing YOU - the second-person voice in two Irish novels". La entrevista que sigue tuvo lugar en el trascurso del congreso y ha sido actualizada en los últimos meses en encuentros personales y correspondencia, especialmente en lo que concierne a sus recientes publicaciones y a su éxito editorial.

Palabras clave. Nuala NíChonchúir, You, segunda persona narrativa, relaciones de pareja, cuerpo, escritoras, tradición irlandesa.

\begin{abstract}
Nuala, I will start with a question that has been addressed to you in previous interviews. When I first approached your work it struck me that you have such a wide and diverse literary production. You are prolific, multifaceted and multitalented. You have written poetry, flash fiction, short stories, novels, essays, literary criticism and even a short drama play. Is it easy for you to find a voice in all these literary genres? Do you plan ahead the form that best serves your purposes or does it come to you in a more intuitive and natural manner? Also, which genre is the one you feel most comfortable with?
\end{abstract}

Fiction is my thing, really, but I suppose that if I were given a choice and told that I could only write in one genre, then, I would pick the short story. I love short fiction because it offers a real challenge and every time you sit down to write you are starting a new story, which is difficult in one way but exciting in another. So you come to a story, which is completely different to the last one you wrote, maybe in tone or in character. Everything is new. As a reader, I love stylistic writing and, as a writer, I aim for that as well. I like the writing of John Banville, for instance, he is very attentive to language. As I was saying in my lecture about Edna O'Brien, she talks about language being sacred to her. I feel the same way. I was brought up bilingual. My schooling was all through Irish and my home life was all through English. So I was living between two languages all the time, and I have just always loved language.

At the moment, I am finishing my third novel. The second one, The Closet of Savage 
Mementos, is coming out in April 2014. Now that I am writing the third one, I find the length of the novel very comforting because everyday you have somewhere to start again. You come back to your desk and you are moving forward, whereas with the short story, if you write it in a week or two weeks, or a month, you are starting again very quickly. Both things suit me. I find when I am writing a novel that I do not have time for a longer short story. So, I write short-short stories while I am writing a novel. In a way, they present themselves to me but in another way it is a break from the novel. You just divert your attention. The novel I am writing now is historical, set in America in the $19^{\text {th }}$ century, and concerns an Irish person, Emily Dickinson's maid. So it is really fun to write a modern short-short story to get away from that for a while. I have a short attention span and so it suits me, as you were saying, that I am a multi-genre writer. It suits me to write long fiction, short fiction, poetry sometimes not a lot- and then drama. I have written a collaborative play with some other people. That is really my only foray into drama.

I suppose historical novels are difficult to write because you need to know a lot about the context and they involve a lot of research. However, it is a genre that is gaining popularity and that it seems to have been revived in the last years.

I think it is very appealing. With Hilary Mantel winning the Booker twice it is certainly a genre gaining interest. I like reading historical fiction. I had attempted one previous historical novel. I wrote most of it and then it just didn't work, so I abandoned it. Then I came up with the story for Miss Emily.

Could you advance something about your second novel, which will be published in spring 2014? Is it a historical novel as well?

No, it is set in 1991 between Dublin and the Highlands of Scotland. When I finished university I went straight to Scotland to work, just as something to do, and the book is set in the place that I went to, a fishing village in the Highlands. It is enjoyable to write about places that you know and you have lived in. When I finished writing the novel I went back to do some last bits of research, which is something I like to do. In October 2013 I was in Massachusetts to complete research on my third novel while I also did some teaching and gave talks at Bay Path College.

Does that mean that you rely on autobiographical material for the writing of your novels and short stories?

I do more so in my poetry, which is very autobiographical. It is generally about my life. My fiction is not so much, but I think setting is hugely important to fiction and I do like to set my fiction in places that I know well. It would be rare for me to set a story somewhere where I have never been. I love to be able to describe a setting. I have set quite a lot of stories in Paris; I try to go to Paris at least once a year. But even if I am writing a story about a city, I have to go back to double, triple check everything, just to make sure that it's all fine. That's the fun part.

You have often referred to the way you organise your time to write, in slots, making the most of it when your children are at school. Do you see yourself as a methodical and disciplined writer? How do you actually invoke inspiration in those hours?

Writing is my job. I have one child in college, one in school and one in a crèche. When they are gone from the house from 9:00 to 12:30, I have three and a half hours, five days a week. So, I get them out of the house and then I sit at my desk and I start. It is a matter of turning up to the desk, and then the work will flow. Routine really suits me. I would be slightly obsessive-compulsive about being organised but, paradoxically, when I write I have great personal freedom. As a person, I like to be on time, you know, that type of thing. I like my time to be organized, but as a writer I can pour myself out very freely and that is a lovely thing. I have a great indiscipline within my writing and I feel a great freedom when I write.

Even though the variety of issues addressed in your writings is wide and diverse, there are some that keep reappearing, like male and female relationships, the body or even sex. Are you aware of this recurrence, are they conscious interests that you have or do they just keep re-emerging?

Like all writers I have my passions: things I am 
deeply interested in. I suppose for me these things are the break down of love, the body as part of that, and the body and sex. And then, other things I like to write about are visual arts and the mother-son relationship. Those are the kind of themes that can be linked but they can also be sorted out separately. They are just aspects and issues that obsess and possess me and, therefore, I write about them all the time.

Edna O'Brien seems to be one of your most admired writers, a real foremother. Which other authors would also be significant for you, considering that you have affirmed that you resist the notion of influence - in "A Trio of Irish Short Stories"?

I very much like Anne Enright. When I was at school we studied short stories and there are three that got me very interested in this form. They are all by men: Oscar Wilde's "The Happy Prince", Brendan Behan's "The Confirmation Suit" and Sean O'Faolain's story "The Trout". These are the three stories that I remember from childhood because I was really affected by them, whether it was the humour or that they were melancholic. Whatever was in them, there was something very attractive to me about those stories. We studied them at school and I probably read them at home as well. And then, when I think of what I wanted to read myself, I would have chosen a lot of English classics in my early teens as they were in the house. But when I started to buy for myself, I went to Anne Enright, Mary Morrissy, Éilís NíDhuibhne -these were writers whom I had never read before. They were writing about women and about women's lives, in and out of the bedroom. They were writing sort of bold, in terms of brave, stuff. My mother had already introduced me to Edna O'Brien when I was very young because she is a fan of hers, both as a person and as a writer. My parents collect books of Irish interest, so our house was always full of Irish books and still is to this day. There has never been a lack of stock to read in their house. I read Mary Lavin and Elizabeth Bowen and all those writers when I was quite young. I feel now, some thirty years later, that I need to go back and read them again to refresh them in my mind.

Most of the writers you have mentioned belong to the Irish tradition. Are there any

\section{other important figures outside Ireland?}

Yes, I love the Americans, particularly the contemporary Americans. There is a short story festival in Ireland in September, The Cork Short Story Festival, to which I go every year. Normally I have a job to do there. I am either interviewing someone or I am reading, but even if I am not working at it, I go. And there, quite often, the people who are shortlisted for the Frank O'Connor Prize are American writers. We love the American writers in Ireland. So through it I have been introduced to Ron Rash, Wells Tower, Manuel Muñoz. Probably, I would not have heard about them ordinarily. Caitlin Horrocks and Valerie Trueblood are two more. American writers are fabulous. I love their writing because I think they do the short story so well. And then, there are English writers like David Constantine who I think is a very, very fine writer. The English have sort of revived themselves in terms of the short story in the last few years. They have taken a deep interest in promoting it there. So, we are getting to hear about young writers like Adam Marek and Alison MacLeod, who is Canadian, but she lives in the UK. And there are of course the Canadian themselves. I love Alistair MacLeod. It is harder to access European writing in translation in English. There is an anthology, Best European Fiction, ${ }^{2}$ through which we get a clutch of short stories translated into English. It is kind of aimed at the American market but it is very useful for us in Ireland as well to see what our European counterparts are writing. People like Peter Stamm are included. It is difficult to know what they are doing unless they are translated well into English.

I would like to focus now on your debut novel, You, which I found both unusual and very special in both form and content. How did that story come to you?

It started from a short story, from my first collection, The Wind Across the Grass. The story was called "Anything Strange or Startling?". I was enjoying writing in the voice and I wanted to write forward from where I had

2. NíChonchúir refers here to a series of books published annually by Aleksandar Hemon, as the general editor. 
the character to see what would happen, with her mother not well and the girl being almost a little mother in the family. I just kept writing and it grew. I then realized that I was writing a novel, which took me a year to complete, between 2003 and 2004. Then, it languished with my then agent for five years until I took it back and it was finally published in 2010 by New Island. So, by the time it came out, it was already, for me, seven years old. I subsequently had a short story collection with New Island and they are publishing my next novel as well. I really enjoyed writing the novel and I never really lost faith in it, even though my agent got a lot of rejections for it. I always believed that it was good enough to be published.

Why does the protagonist of You not have a name? She is called "Miss Prim" by her mother because she is such a responsible child, but this is more the function she performs than a real name.

Yes it is. It didn't start off deliberately that she wasn't named. I just noticed it and then I used it as a device, to expand on the idea of being anonymous. This means that even though she is the very intimate voice in your ear, as you are reading the book, you do not actually know her name and you realise that after a while. I only remembered afterwards that Edna O'Brien had done the same thing in A Pagan Place with her female narrator. I love that book.

Although the use of the second-person narrative in $\mathrm{You}$ is not, to me, the most important aspect of the novel, it has been the focus of attention of most reviewers. Could you expand a bit on the use of the secondperson narrative? Will you choose this form again in successive short stories or novels?

Yes, the title story for my first book, The Wind Across the Grass, is written in the second person. I won the Francis MacManus Award for that in 2002, and that was my first big award. I wrote another one last year, a story about Frida Kahlo that was also in the second person. I just love it and I love writing in it but I have to stop myself doing it a lot. I am not hugely comfortable with the third person. I have written very little in the third person. It is either the first person, for me, or the second. That's what I like, but I try not to do the second person too much because I don't want to be seen as a one-trick writer. I actually love the present tense as well, which is another thing you are not supposed to do. You is written both in the present tense and in the second person voice. Double-whammy!

You mentioned this morning in your lecture that there are other writers who have used the second person voice -apart from Edna O'Brien in A Pagan Place-, such as Italo Calvino in If on a Winter's Night a Traveller and Jay McInerney in Bright Lights, Big City, among some others. From the perspective of a writer, was it challenging in the sense of demanding at succeeding to engage the reader?

As long as they engage with it and, in a sense, forget about it and just accept that this is the way it is written. The reader can either choose to be irritated by it or let herself get into it. It seems, judging by the reviews the novel received, that the readers were irritated at the beginning but eventually allowed themselves to get into it, so, they didn't resist it. And after a while they didn't even notice the second-person voice.

In my case, I felt it gave a sense of intimacy and immediacy in the process of empathising with the characters.

Yes, you are right there with the characters. It is very enjoyable to write as well because it keeps you on your toes. Third person past tense is normal but first person present tense is more challenging for you as a writer, and I would rather sit down and be challenged as I write than dash off a load of very easy and ordinary lines. In a way, I like when the writing is difficult, not when I have to fight with it, but when I have to work very hard with it. For the book I am doing now I have to do a lot of research, which is hugely enjoyable, although I have to make sure not to spend too much time doing that and then neglecting the actual writing of the book. I set myself a word count to make sure that I write a certain amount per week, so that it has to build up. I have an agent waiting for the completed novel.

Considering its innovative quality, would you define $Y o u$ as an experimental narrative? 
In a sense, yes. There is this perception of the second-person voice as a tricksy thing, but for me it's a very Irish thing. It is a very Irish way to tell a story, very intimate but also back slightly. In a way, I do not find it tricksy at all. I know other people do, and they think you are trying to be smart or funny by using it. But I just find it is very natural; it comes very naturally to me when I sit down to write, and even when I talk. Sometimes I talk in the "you", so I am not talking directly about myself. And I find it very easy to sustain over the length of a novel. I sat down everyday for a year to write You and I would just slip into it, really naturally. I think the only experimental element to it is the second-person voice. Otherwise, it is quite a straight narrative with a straight plot in which two major happenings take place and there are a lot of other small things that are feeding off the main events.

Would you agree with an interpretation of You as the story of a dysfunctional family going functional in the end?

Yes, they are trying to. The child is the mother figure. She is minding her mother and her brothers. She is striving for the normalcy that she sees in others people's families. They all look so happy to her. I mean, little knowing of course, that other families are not probably that happy. So, she takes the decision that if her mother is not going to look after her little brother, she is going to do it herself. Her drastic solution is to run away, which is a sort of a typical child solution: "I'll remove myself from the place of potential danger", not knowing that they are putting themselves in possibly even further danger. And then, the perceived normalcy of her father's life is not good either, because his new partner is hostile towards the children, particularly towards her brother, and so the girl feels she has to take him out of the way. This new place is almost worse than the old one and therefore she is constantly moving from place to place to try and find a balance, and she perceives her friend Gwen as having the perfect family: mother-father-daughter. So, she thinks, "I'll go there, and there I'll be safe", that sort of thing.

As a reader, it is heartbreaking to see how the girl is aware of the fact that her friends are now allowed to go to her house because their parents have reservations about the way her mother handles the family and the chaotic state of the house. For a child, this can be a very alienating experience, feeling that she is being rejected because she has a "different" kind of family that does not conform to societal expectations. Was the idea of a conservative nuclear family the target for your criticism?

I wanted to show that peculiar kind of Irish snobbery. The novel is set in 1980 and people who were separated, were very much noticed and frowned upon then. Joan was a single parent family, even though she was separated, but she was on her own and her third child was from a different relationship. So, all these are issues that get visited upon the child. Nothing has to be said. The child is just aware of the "we are not like them". In a way, we happen to be like them, because we are ourselves. But then, when the mother keeps disappearing that's when the difficulties arise. There is that Irish thing of looking down the nose at other people, not knowing what is going to be visited upon your own family. It's a dangerous stance. I was one of those children, I was always observing, watching and noticing how adults behaved, how what they did, or did not do, was loaded. In my family, we did not have a huge circle of friends as children. My parents did not drink, so they did not go to the pub. We lived a bit away from the town, so there would not be a lot of other people visiting the house. Those we knew were few and you would see them very clearly, or at least I did as a child. I could kind of pick them up very clearly. I was always watching.

To me, a very important aspect of the novel is the contrast established between the two settings: the semi-urban, where the girl lives a sort of unstructured life; and the urban, in the suburbs of Dublin, where her father apparently leads a happy live even though the area is rough. In fact, the girl is threatened and shocked by the violence of other children. Ironically, where she lives with her mother, even though it is described as a dysfunctional household, is in effect safer and more communal. In between the two landscapes, the river seems to emerge as 
a unifying force. Could you expand on your interest to make the girl have to confront such opposed settings and also on the function of the river, which is utterly personified?

I grew up beside the river Liffey, it was 500 yards from our door. As children we played in it and on it, in boats. We went swimming and we fished in it. It was a huge part of our lives. Everyday people would mention the river: "Oh the river is very high today" or "You can see the river bed...". So, when you live beside a river, it is a huge part of your life and, particularly, I suppose because it is the Liffey, one of the main rivers in Dublin, which goes into the city. The place where she lives is where I grew up in Mill Lane, in Palmerstown. There are fields, the river Liffey and the weir, which she listens to at night, like a lullaby, and which I listened to at night. The house I set the book in is a house built into the river, which is called "Rose Cottage". The narrator's father lives in Ballymun. It is not named in the book but it has high-rise towers. When you live besides a river, besides cows and fields, and you go ten miles away to find these high-rise towers and concrete, it can be quite frightening if you are a child. You do not understand those really stark urban landscapes. When I was a child I thought it would be hell to live in one of those, and that's what she feels like, that it is actually hell. She can't hear anything except airplanes going by because the airport is nearby. Everything is grey and different, even the rain. While her mother's house and the atmosphere there is not ideal, at least it is her place, and the river is there, as a comfort. But then her comfort suddenly becomes a place of huge threat when her baby brother dies.

Yes, that part really broke my heart. The way it was described was very vivid, especially when she holds the baby and carries him back home, already dead. In a way, it reminded me of Frank McCourt, who was also good at picturing irresponsible male figures. The girl had only gone for a walk with Cora and they had left the baby with Rory and Noel. They were supposed to mind him while they were playing cards and drinking but they didn't. This emphasis on male irresponsibility has emerged in many
Irish novels, including Angela's Ashes. I wonder whether this text could have been in the back of your mind.

It wasn't conscious, if it was. Obviously, I have read Angela's Ashes and loved it. It made me laugh and cry. It was a wonderful book and he was a wonderful man. But I would not have it in mind, solely, because I grew up beside the river and my cousin drowned. She actually drowned in the canal when she was five and I was the same age. So, drowning has always lurked in my brain, like a threat. We were warned not to go near the river but we were always by the riverside, paddling, catching minnows or whatever we could do. We were just drawn to it. But there were always rumours of drownings and my father, who is a great oral storyteller, would tell us about a time a nurse from the hospital beside where we lived drowned. He found her watch down beside the river. There was also another story about a little boy who drowned, although he wasn't a baby. So, all of these things lodge in your head and they warn you away from the water. Besides, there is always that thing that while you love the river and it is beautiful and your uncle brings you out in a boat, it is also very threatening and dangerous because there are whirlpools and all sorts of things. We were warned about it but we were drawn to it anyway.

In the novel, paradoxically, when the baby dies things start to be put in place. While the girl was initially caught in between two families, eventually the two households seem to bridge the gap and unite in a multi-family reunion that changes the tone of the novel. Do their sharing of the loss and their grieving symbolize an urgent need to come to terms with their differences?

This is about separated couples and myths. People think that they will never get on and I wanted to show the reverse. The father knows that he has to support his ex-wife Joan and it's not a big deal. In a background sense, they were childhood sweethearts. He knows her very well, and for a long time. So he eventually comes back to her because she is not coping on her own. I wanted to end the book on an uplifting note. I do not know why. It is not that 
it is a Hollywood ending but I just felt for them. It was important that you left this girl not feeling that she did not know what was going to happen next, rather that it was more likely to show that her mother would learn how to love her two children and care for them properly. Out of tragedy comes some type of redemption for her. She now has to stop drinking and care for the children she has. So I think it gets better from here on for them.

I also thought the novel was very modern in the sense that, although it is set in the 1980s, when divorce and abortion were still banned, it portrays two different families: one formed by a separated woman with children from different fathers and no stable relationship; and the other, a newly-formed couple that adds further half siblings.

Yes, I have seen that, I suppose, growing up. These people were always be approved of. But they were your neighbours. They were the people living near you, anyway. I think we can pretend -and Irish people pretend a lot- that these people are not there but they have always been there. When you talk to people, they have different types of families and different ways of bringing up their children. And a lot of children were brought up by their grandparents, for whatever reasons. That was common when I was growing up.

Yes, that was exactly my point, that although it was set in the 1980s, it explored a reality that transgressed received assumptions about the traditional Irish (Catholic) nuclear family. Connected to this, I am very interested in how you depict the motherdaughter relationship, and especially in this "mothering-daughter" subject, which is a much wider theme that appears in other Irish writers such as, for instance, Claire Keegan. In her stories, there are many abject and unable mothers, and the daughters are the eye openers, the key figures who take responsibility over the household and play important roles as regards the awakening of their own mothers.

In Ireland our mothers were so swallowed up in Catholicism and so pushed down by it, that we as their daughters are educating them. We tell them it was all wrong, wrong to suffer, or to feel that you had to have seven or ten children. And some of the older mothers are now realising that. Actually the church was not a positive influence in my life. A lot of mothers now say that they really admire that their daughters can go out to work. But there are others who are resentful because, as there was no contraception, their generation was trapped at home with all these children. There was also that sort of divide between women who got an education and women who didn't. The educated women could get contraception, maybe from the North or wherever, whereas the others were still under the thumb of Catholicism. I see that from my own mother. She says now that she was tricked by the Catholic Church into having seven children. She knows she would not have had seven had she had a choice, but she did not feel she had and she just went along with what her husband said, and my father was very Catholic. She was too, but she would tell us "I wasn't even listening to the priest at Mass" and then we were shocked. We would say, "Oh, but we have to listen?" They had a terrible time trying to figure it all out.

Let me ask you now about the male characters in You. Were you deliberately portraying them in a negative way or did they just come out that way?

No, no. I was interviewed last year about Mother America by a young male writer and he said that the men in my stories are terrible, horrible. I was kind of heartbroken. I said no, they are lovely, they're normal. They are just human and have flaws, but the women are flawed as well. I am a feminist, but a feminist who loves men. I am surrounded by men. I live with three men and I don't deliberately set out to show men in any terrible light, no more than I set out to show women in a bad way. I am just trying to show how relationships can be. They can be nasty and people can have improper motivations. It is very interesting to write these flawed characters. The "man behind the curtain" in You is Kit, the mother's new boyfriend, whom she knows very well because he is Noel's brother. I deliberately made him a butcher which, from a child's point of view, would be oddly fascinating and strange. $\mathrm{He}$ comes to the house and his gifts are meat for 
the family, and the narrator comments: "Oh, Eugene always brought mammy flowers, you know?". And he would answer, "Flowers won't feed a growing family". So, he is bringing this very practical present that has to do with him and his job, but the child just sees him as a butcher in a bloody apron. I was trying to use his profession to make him appear less nice as a person, from the wary child's POV. But there is nothing wrong with butchers and there is no man-hating going on!

You just mentioned something very interesting. Very few women writers in Ireland nowadays would admit that they are feminists even though their novels or short stories often and unmistakably reveal a gender agenda. Still, most refuse to be labelled. How do you feel about feminism in Ireland?

I think it is terrible that a feminist would deny it. Éilís NíDhuibhne is a feminist and says it, Anne Enright calls herself a feminist, and these are writers that I admire. That is part of the reason why I admire them. There is a new wave of feminists in Ireland of my age group, thirties and forties, who are very happy to call themselves feminists. We have a now defunct website that is called "The Anti Room". ${ }^{3}$ But the conversation is open, lively and becoming more audible.

\begin{abstract}
After Kate O'Brien?
Yes, but "anti", with an "i". There are a lot of women from the media, journalism and writing. We all used to write non-fiction articles. I was writing an article for the Anti room and I interviewed a lot of women artists and writers to see whether they would identify specifically as feminists, and I was surprised by some of them who said "no".
\end{abstract}

Do you have any favourite short story or novel? Which story took you longer to write or you enjoyed more/least?

It's very hard to even like your own work once it's done never mind cite a favourite. Though I am fond of my collection Nude (Salt, 2009) which deals with the nude in art and in life. I enjoyed writing those stories and they cohered well.

\section{What is your ultimate wish as a writer?}

For my work to be read. And, hopefully, enjoyed.

Thanks very much for this, Nuala. And good luck!

3. See the following webpage:

http://theantiroom.wordpress.com.

Received $22^{\text {nd }}$ February $2014 \quad$ Last version $24^{\text {th }}$ February 2014

Marisol Morales Ladrón is Senior Lecturer in English and Irish literature at the University of Alcalá (Madrid, Spain). Her main area of research is contemporary Irish literature and she currently chairs the Spanish Association for Irish Studies (AEDEI). She also works in the field of gender studies and in the interrelationship between literature and psychology. Her publications include the books Breve introducción a la literatura comparada (U of Alcalá, 1999) and Las poéticas de James Joyce y Luis Martín-Santos (Peter Lang, 2005). She has edited the volume Postcolonial and Gender Perspectives in Irish Studies (Netbiblo 2007) and has co-edited the monograph Glocal Ireland: Current Perspectives on Literature and the Visual arts (Cambridge Scholars 2011), as well as two other studies on feminist criticism: Mosaicos y taraceas: Desconstrucción feminista de los discursos del género (U of Acalá 2000) and (Trans)formaciones de las sexualidades y el género (U of Alcalá 2001). She has published articles on a variety of English and Irish authors. 